http://dx.doi.org/10.12775/szhf.2019.011

EMILIA ZAWADZKA

Uniwersytet ŁóDZki, Polska

ORCID: 0000-0002-3897-2273

E-MAIL: LIYAH13@O2.PL

\title{
Baruch Spinoza i jego związki z filozofią Kartezjusza Problem myślenia ludzkiego
}

\section{Wprowadzenie}

W swoich pismach Baruch Spinoza często ukazuje główne idee filozofii za pomocą kartezjańskich pomysłów oraz argumentów. Zamierzenie to widać szczególnie w problematyce metafizycznej. Niderlandzki myśliciel już pod koniec lat pięćdziesiątych XVII wieku uważany był w kręgu intelektualnym za wybitnego badacza koncepcji Kartezjusza. W tradycji filozoficznej przyjęło się traktować Spinozę jako tego, który podjął na nowo problematykę kartezjańską, by w rezultacie zaproponować nowe rozwiązania klasycznych problemów powstałych na gruncie systemu autora Medytacji ${ }^{1}$. Całe to przedsięwzięcie wprowadza również na grunt filozofii Spinozy pewne napię-

\footnotetext{
${ }^{1}$ Według Jolanty Żelaznej dotychczasowe badania nad spinozyzmem najczęściej koncentrowały się wokół takich zagadnień jak panteizm, monizm, amoralizm czy ateizm. Interpretatorzy myśli Spinozy rzadziej skupiali uwagę na kwestii dotyczącej interpretacji filozofii Kartezjusza
} 
cie, które jest widoczne w podejściu do następującego problemu: czy istotę ludzką ze względu na przynależną jej funkcję myślenia możemy traktować jako rzecz ontycznie wyjątkową? W pracach Spinozy można mianowicie znaleźć bliskie Kartezjuszowi stwierdzenia, że sfera myślenia oraz umysłu jest niezależna względem wszystkiego, co rozciągłe, i że nie da się jej wyjaśnić materialnymi przyczynami. Co więcej, według niderlandzkiego filozofa w pełni rozwiniętym myśleniem - świadomym myśleniem rozporządzają wyłącznie podmioty ludzkie. Nie jest to jednak jedyna możliwa interpretacja Spinozy, ponieważ można uznać, że świadomość ludzka nie jest żadnym odrębnym bytem. W przeciwieństwie zatem do Kartezjusza niderlandzki uczony nie uważał, że twierdzenie o różnicy między myśleniem a cielesnością nieuchronnie prowadzi do uznania podmiotu ludzkiego za byt ontycznie wyróżniony. Sfera myślenia okazuje się wyłącznie filozoficznym mitem. Wbrew często wyrażanej opinii dziedzina umysłu nie czyni człowieka bytem wyjątkowym, nawet gdy weźmiemy pod uwagę, że ludzkie myślenie jest bogatsze od myślenia pozostałych bytów w przyrodzie.

Niniejszy artykuł składa się z kilku części. W pierwszej postaram się przedstawić ogólne uwagi dotyczące natury myślenia, kładąc nacisk na to, że Kartezjańskie przeświadczenie o tym, że myślenie stosuje się tylko do wybranych rzeczy w przyrodzie, może skutkować pewnymi trudnościami. W kolejnej części zajmę się Spinozjańską argumentacją na rzecz tezy, że myślenie nie stanowi własności decydującej o wyróżnionej pozycji bytu ludzkiego. Pytanie, które należałoby postawić w odniesieniu do Spinozy, sprowadza się do tego, czy i na podstawie jakich argumentów można przypisać mu pogląd, że człowiek w pewnym sensie wyłamuje się jednak z pozostałych rzeczy w przyrodzie. Odpowiedzi na to pytanie nie należy szukać przez odwołanie się do faktu myślenia, które w kartezjańskim systemie sytuowało jednostkę ludzką poza przyrodą, lecz w spinozjańskiej sferze moralnej. To zdolność umysłu ludzkiego polegająca na zrozumieniu, że człowiek jest integralną częścią natury, zdolność do osiągnięcia szczęścia oraz wolności powodują, że istotę ludzką możemy nazywać bytem wyjątkowym.

dokonanej przez niderlandzkiego myśliciela. Jolanta Żelazna, „Wstęp”, w: Skończone poznanie ludzkie w filozofii Spinozy, (Toruń: Wydawnictwo Uniwersytetu Mikołaja Kopernika 1995), 8. 


\section{Natura ludzkiego myślenia}

Czy człowiek jest bytem wyróżnionym z uwagi na myślenie? I na czym wówczas ta wyjątkowość polega? Jak dużą wagę przykładamy do odróżnienia nas od pozostałych bytów w przyrodzie? W jaki sposób taka wyjątkowość, jeżeli istnieje, jest osiągalna?

Pojęcie człowieka jako odrębnej substancji wyposażonej w określone atrybuty, w tym oczywiście atrybut myślenia, odgrywało $\mathrm{w}$ wielu koncepcjach filozoficznych rolę fundamentalnej i finalnej podstawy, do której sprowadzają się wszelkie wyjaśnienia. Poważny krok w kierunku odizolowania człowieka od przyrody i podporządkowania mu jej zawdzięczamy Kartezjuszowi. Uznaje się go za prekursora antropocentrycznego przełomu w kręgu filozofii europejskiej. Skoncentrował się on na jednostkowej jaźni myślącej górującej znacząco, jego zdaniem, nad światem materialnym. Stadium wyjściowym było dla Kartezjusza wątpienie metodyczne. Postawa ta miała swoje uzasadnienie $\mathrm{w}$ gwałtownych przemianach światopoglądowych przełomu średniowiecza i nowożytności, totalnej zmianie obrazu świata, upadku autorytetów czy narastającej niepewności epistemologicznej spowodowanej brakiem absolutnego i niepowątpiewalnego kryterium prawdy. Zwątpienie we wszelką dotychczasową wiedzę zaowocowało doniosłym stwierdzeniem „myślę, więc jestem”2. Kolejne pokolenia filozofów na swój sposób kontynuowały tę tradycję i zwracały się w stronę dotychczas odmiennych tropów, a mianowicie w stronę ludzkiej świadomości i ludzkiego postrzegania ${ }^{3}$.

2 „Lecz już przyjąłem, że nic w świecie nie istnieje: ani niebo, ani ziemia, ani umysły, ani ciała, czyż więc nie przyjąłem, że i ja nie istnieję? Ja jednak na pewno istniałem, jeśli coś przyjąłem. Lecz istnieje zwodziciel - nie wiem, kto nim jest - wszechpotężny i najprzebieglejszy, który zawsze rozmyślnie mnie łudzi! I niechajże mnie łudzi, ile tylko potrafi, tego jednak nigdy nie dokaże, abym był niczym dopóty, dopóki będę myślał sam, że czymś jestem. Tak więc po wystarczającym i wyczerpującym rozważeniu wszystkiego, należy na koniec stwierdzić, że to powiedzenie: »Ja jestem, ja istnieję«, musi być prawdą, ilekroć je wypowiadam lub pojmuję umysłem”. Kartezjusz, „Medytacja druga: O naturze umysłu ludzkiego. Że jest on bardziej znany niż ciało", w: Medytacje o pierwszej filozofi, przeł. Maria i Kazimierz Ajdukiewiczowie (Warszawa: Wydawnictwo Naukowe PWN, 2010), 31.

${ }^{3}$ Anita Ganowicz-Bączyk, „Wpływ nowożytnego antropocentryzmu na relację człowieka do przyrody. Część pierwsza", Studia Ecologiae et Bioethicae 9 (2011): 15. 
Dla Kartezjusza wyjaśnienie kwestii ludzkiej świadomości powinno poprzedzać próbę rozwiązania jakiegokolwiek problemu. Jeżeli chcemy dowiedzieć się, jakie muszą zostać spełnione warunki, aby możliwa była prawdziwa wiedza, bądź jakie są warunki bytu w ogóle, konieczne jest wyjaśnienie zagadnienia następującego: dlaczego to, czy dane poznanie jest prawdziwe, czy dany byt istnieje, wydaje się nam problematyczne? Innymi słowy: skąd bierze się i na czym polega to powątpiewanie, które skutkuje zadawaniem takich pytań? W Medytacjach o pierwszej filozofii Kartezjusz starał się rozjaśnić te wątpliwości. Mamy tam do czynienia z pewnym repertuarem argumentów, który okazał się przekonujący nie tylko dla ówczesnych francuskiemu uczonemu myślicieli ${ }^{5}$.

Jaka jest natura myślenia? Czy niepowątpiewalna wiedza jest w ogóle możliwa? Czy świadectwa zmysłów są godne zaufania? Czy mogę polegać na tym, co podsuwa mi rozum? Jaki obraz otrzymuję za pośrednictwem tych władz? Czy jest to sprawozdanie dotyczące jakiejś niezależnej względem podmiotu rzeczywistości, czy sprawozdanie odnośnie do aktualnego stanu podmiotowej jaźni? To wahanie doprowadza do rozważań nad naturą myślenia. Najogólniej rzecz ujmując: myślenie jest pewnym procesem, w którym dochodzi do odwzorowania danego wycinka rzeczywistości, bądź jest procesem coś reprezentującym. Odwzorowanie polega na tym, że myślenie zawiera poszcze-

${ }^{4}$ Krzysztof Michalski, „Husserl i Kartezjusz: Kiedy świat wydaje nam się niezrozumiały”, Studia Filozoficzne 4 (1985): 3.

${ }^{5}$ Dobitnie potwierdzającym to przykładem są Medytacje kartezjańskie Husserla. Kartezjańskie argumenty oraz metafory zostały w dziele niemieckiego myśliciela podjęte na nowo. Mimo że Husserl doszedł do diametralnie innych wniosków oraz rozwiązań niż jego poprzednik, to oś myślowa z Medytacji o pierwszej filozofii pozostaje nadal bardzo widoczna. Husserl następująco to przedstawia: „To, że wolno mi mówić o fenomenologii transcendentalnej tutaj, w tej najszacowniejszej z siedzib francuskiej nauki, ze szczególnych powodów napełnia mnie radością. To bowiem największy myśliciel Francji, René Descartes, dał jej poprzez swe Medytacje nowy impuls, to studiowanie ich zawartości wpłynęło całkiem bezpośrednio na przekształcenie się powstającej już fenomenologii w nową postać filozofii transcendentalnej. Stosownie do tego, można by ją prawie określać jako neokartezjanizm i to bez względu na to, w jak wielkiej mierze fenomenologia ta - właśnie na drodze radykalnego rozwijania kartezjańskich motywów - zmuszona jest odrzucać niemal całą rozpowszechnioną teoretyczną zawartość filozofii kartezjańskiej”. Edmund Husserl, „Medytacje Kartezjusza jako wzór filozoficznej autorefleksji”, w: Medytacje kartezjańskie, przeł. Andrzej Wajs (Warszawa: Wydawnictwo IFiS PAN, 2009), 1. 
gólne informacje odnośnie do jakiegoś tematu oraz dostarcza je. Ponadto zgodnie z funkcją reprezentacyjną myślenie jest zawsze o czymś, zawsze odsyła do czegoś. Myślenie jest zatem w każdym przypadku treściowo określone. Informacje w nim zawarte charakteryzują się pewną formą. W procesie myślowym wykonujemy pewne działania na treściach. Należy również zwrócić uwagę na fakt, że struktura myślenia określana jest przez różnego rodzaju relacje, np. relacje skojarzeniowe czy relacje sensu. Niektóre przypadki myślenia przedstawiają coś, co można określić mianem samozwrotności. Jest to taki proces, w którym myślenie odsłania jakoby samo siebie. Ze względu na to stosuje się pewne rozróżnienie na myślenie pierwszego i myślenie drugiego rodzaju. Ten drugi rodzaj to myślenie samozwrotne, które traktuje się jako refleksyjne oraz świadome. Myślenie pierwszego rodzaju, a mianowicie proces rozumiany jako zdolność działania na treściach, może odbywać się bez aspektu samozwrotności. Odbywa się wtedy ono bezrefleksyjnie, nieświadomie ${ }^{6}$.

Warto zwrócić uwagę na fakt, że w myśli filozoficznej Kartezjusza ludzkie myślenie może mieć wyłącznie charakter świadomy, a więc jest takie wszystko to, co zawiera się w umyśle ludzkim. Innymi słowy nieświadome myślenie jest niemożliwe. Oczywiście w systemie kartezjańskim własność ta jest przypisana wyłącznie ludziom. To, co zwie się myśleniem, jest udziałem jedynie człowieka z powodu jego istotnej odmienności wobec reszty przyrody. Doświadczenie charakteryzujące nasze naturalne nastawienie, doświadczenie potoczne skłania nas ku przeświadczeniu, że większość spośród otaczających nas rzeczy nie zdradza oznak myślenia ${ }^{7}$. Wydaje się, że stosowanie kategorii

${ }^{6}$ Przemysław Gut, „Panpsychizm: czy człowiek jest bytem ontycznie wyjątkowym ze względu na myślenie?", w: Spinoza o naturze ludzkiej (Lublin: Wydawnictwo KUL, 2011), 88-89.

${ }^{7}$ Kartezjusz również zwierzętom odmawiał jakiejkolwiek zdolności do myślenia i odczuwania. Traktował je wyłącznie jako zwykłe mechanizmy, które w dodatku nie odczuwają bólu. Dla francuskiego myśliciela człowiek odróżnia się od zwierzęcia tym, że posługuje się rozumną mową, i tym, że jego działanie jest oparte na regułach rozumu. Ponadto istota ludzka wykazuje się zdolnością do wykonywania zadań uogólnionych. Najprościej rzecz ujmując: zwierzęta w przeciwieństwie do ludzi nie dysponują rozmaitymi mechanizmami, nie charakteryzuje ich wszechstronność rozumu. Gdy mowa o działaniu, człowiek ma zdolność adaptacji do zmiennych warunków otoczenia. Czynności zwierzęt z kolei są zdeterminowane i ograniczone danymi warunkami. Argumentacja Kartezjusza odmawiająca zwierzętom własności myślenia jest częścią wywodu dotyczącego niezależności substancji niematerialnej - umysłu od substancji materialnej ciała. Co więcej, wiąże się z argumentacją odnoszącą się do nie- 
myślenia wyłącznie do jednostki ludzkiej ma związek z założeniem o wyróżnionej pozycji człowieka. Czy twierdzenie, że człowiek ze względu na przynależną mu funkcję myślenia jest bytem wyjątkowym, jest samo przez się oczywiste i niepowątpiewalne? Przy dokładniejszej analizie przeświadczenie to może okazać się bezzasadne. Tak też dzieje się na gruncie spinozjańskiego systemu.

\section{Kategoria myślenia a status istoty ludzkiej}

Kartezjańskie przeświadczenie o tym, że myślenie stosuje się wyłącznie tylko do wybranych rzeczy w przyrodzie, skutkuje pewnymi trudnościami. Według Spinozy należy zadać sobie pytanie, dlaczego akurat tym, a nie innym bytom przysługuje myślenie. Stwierdzenie, że po prostu tak jest, niczego nie wyjaśnia. Zdaniem niderlandzkiego myśliciela, jeżeli nie można jakiejś rzeczy zrozumieć, to ona nie może istnieć. Innymi słowy każdy zaistniały fakt można w pewien sposób wyjaśnić. Jeżeli zatem nie można wytłumaczyć tego, dlaczego właściwość myślenia przysługuje wyłącznie ludziom, to taki fakt nie istnieje. Dla Kartezjusza brak zrozumienia czegoś nie jest jednoznaczny z odmówieniem istnienia temu czemuś. Wracając jednak do własności myślenia, według Spinozy, gdy przyjmiemy, że myślenie odpowiada wyłącznie podmiotom ludzkim, to należy uznać, że nie ma dla niego żadnego wytłumaczenia wynikającego z immanentnej natury przyrody ${ }^{8}$. Co więcej należałoby uznać, że myślenie jest jakąś nadzwyczajną własnością mającą swoje źródło spoza przyrody. Wszystko zaś, co istnieje, musi się wywodzić z tej samej zasady substancjalnej (przyrody), która jest jedna i bez której nic nie istnieje i nic nie może zostać zrozumiane.

zdolności ciała rozciągłego - materii do myślenia. Wysunięte przez francuskiego myśliciela uzasadnienie pozbawiające zwierząt myślenia jest umocnieniem stanowiska, że ciała nie mogą być fundamentem myślenia. Paweł Pasieka, „Kartezjańska koncepcja zwierzęcia-maszyny”, Filo-Sofija 17 (2012): 58.

${ }^{8}$ Gut, „Panpsychizm: czy człowiek jest bytem ontycznie wyjątkowym ze względu na myślenie?", 87. 


\section{Spinozjańska argumentacja na rzecz tezy o uniwersalności myślenia}

\subsection{Kategoria substancji a istota człowieka}

Spinoza inaczej niż jego francuski poprzednik pojmował kategorię substancji'. Boga, rzecz materialną, rzecz myślącą zastąpił bytem jednym jedynym. Ponadto postawił znak równości między znaczeniem terminów takich jak „Bóg”, „przyroda”, „substancja”. Nadał im miano jednej jedynej substancji, która przejawia się w nieskończenie wielu modyfikacjach. W rezultacie powstała monistyczna wizja rzeczywistości. Na gruncie spinozyzmu zatem istota ludzka nie jest ontycznie wyróżnionym bytem na tle całej przyrody, lecz jest jedną z nieskończonych modyfikacji substancji. W efekcie człowiek nie przeciwstawia się naturze. Umysł ludzki nie przeciwstawia się rozciągłemu ciału ${ }^{10}$. Są to przejawy jednej i tej samej rzeczywistości.

Spinoza był przekonany, że wykazanie istnienia jednej jedynej substancji jest jednoznaczne $\mathrm{z}$ bezapelacyjnym odrzuceniem możliwości substancjalnej interpretacji jednostki ludzkiej. W przeciwieństwie do Kartezjusza niderlandzki myśliciel uważał, że:

Do istoty człowieka nie należy byt substancji, czyli substancja nie tworzy formy człowieka. [...] Byt substancji obejmuje bowiem istnienie konieczne [...]. Jeśliby więc byt substancji należał do istoty człowieka, to wraz z substancją byłby też dany koniecznie człowiek [...], wobec tego zaś człowiek istniałby z koniecznością, co $[\ldots]$ jest niedorzeczne ${ }^{11}$.

\footnotetext{
${ }^{9} \mathrm{~W}$ tym miejscu należy przypomnieć, że w kartezjańskim systemie tylko Bóg jest substancją sensu stricto. $\mathrm{Z}$ tego względu bytu rozciągłego i bytu niematerialnego nie należy odbierać identycznie tak jak jedynego bytu w sensie ścisłym.

${ }^{10}$ Jolanta Żelazna, „Teoria afektów w Etyce”, w: Substancja jak światło? Wybrane pojęcia i problemy filozofii Spinozy, (Toruń: Wydawnictwo Naukowe UMK, 2010), 108.

${ }^{11}$ Baruch Spinoza, „Część druga: O naturze i pochodzeniu duszy”, w: Etyka w porządku geometrycznym dowiedziona, przeł. Ignacy Myślicki (Warszawa: Wydawnictwo Naukowe PWN, 2010), 71 .
} 
W następstwie tego człowiek jest modyfikacją:

Wynika stąd, że istotę człowieka stanowią pewne odmiany atrybutów Boga. Albowiem byt substancji [...] nie należy do istoty człowieka, [istota człowieka E. Z.] jest więc [...] czymś, co jest w Bogu i co bez Boga nie może ani istnieć, ani być pojęte, czyli [...] jest pobudzeniem, czyli modus, który w sposób ściśle określony wyraża naturę Boga ${ }^{12}$.

Jedynymi rzeczami, które zatem istnieją, są Bóg oraz modyfikacje. W konsekwencji cokolwiek tworzy człowiek, nigdy nie może być wyjaśnione za pośrednictwem substancjalnego sposobu istnienia. Wszelkie zagadnienia poszukujące odpowiedzi na pytanie, co decyduje o bycie ludzkim, muszą sprowadzać się do rozstrzygnięć, że istotę ludzką tworzą pewne modyfikacje jednej i jedynej substancji.

Podsumowując: spinozjański rozum nie jest odrębną i niezależną substancją, tak jak chciał Kartezjusz:

Przez rozum bowiem [...] rozumiemy nie myślenie bezwzględne, lecz jedynie pewien określony modus myślenia, który różni się od innych modi, jak pożądanie, miłość itd., i dlatego [...] musi być pojęty przez myślenie bezwzględne, mianowicie [...] musi przez jakiś atrybut Boga, który wyraża wieczną i nieskończoną istotę myślenia, być tak pojęty, że bez niego ani istnieć nie może, ani być pojęty. Dlatego też musi on [...] zostać zaliczony do przyrody stworzonej, nie zaś do tworzącej, jak pozostałe modi myślenia ${ }^{13}$.

Intelekt zatem to modyfikacja myślenia. Sama istota myślenia zaś konstytuowana jest przez atrybut substancji boskiej. Bez odniesienia do niego rozum nie może ani być, ani być pojęty. Przeświadczenie to zaś pozostaje w ścisłym związku ze spinozjańską zasadą przyczynowości - według niej przyczyna oraz skutek muszą być jednakowe pod względem natury. Ponadto musi istnieć między nimi relacja pojęciowa. Bez tej zasady Spinoza nie mógłby dojść do wniosku, że każdy byt wynikający z substancji boskiej musi charakteryzować się własnością, która jest przejawem danego atrybutu. Podejście to różni się od stanowiska, jakie reprezentował Kartezjusz. Dla niego przyczyna i sku-

\footnotetext{
${ }^{12}$ Spinoza, „Część druga: O naturze i pochodzeniu duszy”, 71-72.

${ }^{13}$ Spinoza, „Część pierwsza: O Bogu”, 44.
} 
tek nie muszą być rzeczami w stosunku do siebie jednakowymi. Samo pojęcie spinozjańkiego myślenia jest bliskie kartezjańskiemu znaczeniu z Medytacji: myślenie obejmowało wątpienie, pojmowanie, chcenie, wyobrażanie sobie, przeczenie itd. ${ }^{14} \mathrm{U}$ Kartezjusza jednak ludzkie myślenie czyni człowieka bytem niezależnym, wyróżnionym, podczas gdy u Spinozy ludzkie myślenie wraz ze wszystkimi swoimi odmianami wydaje się istnieć wyłącznie na mocy odniesienia go do atrybutu jedynej substancji.

Zamierzeniem niderlandzkiego uczonego była integracja człowieka z naturą. Spinoza chciał opisywać jednostkę ludzką nie jako samodzielny oraz samowystarczalny byt, lecz jako nieodłączną część przyrody. Pojęcie modyfikacji uniemożliwia podjęcie dyskusji nad tym, co jest transcendentnym źródłem natury, gdyż stawia znak równości między źródłem a naturą. Spinozjański podział na przyrodę tworzącą (natura naturans) i przyrodę stworzoną (natura naturata) nie jest argumentem przemawiającym za tym, że myślenie jest cudownym zjawiskiem w świecie pochodzącym spoza natury. Na gruncie spinozyzmu podział ten jest rezultatem ograniczoności oraz braku narzędzi ujmowania charakterystycznych dla ludzkiej perspektywy. Modyfikacje Boga oraz pobudzenia ludzkiego umysłu postrzegane są jako aspekty tej samej substancji oraz ukazują, że istota ludzka determinowana jest siłami całej natury ${ }^{15}$.

Spinozjańska koncepcja jednej substancji pozwala uznać człowieka za jeden z bytów wpisujących się w ogólny porządek przyrody. Nie unieważnia jednak wszystkich argumentów na rzecz tezy o ontycznej odrębności, wyjątkowości istoty ludzkiej. Można dowodzić przecież, że człowiek ze względu na własność myślenia, narusza integralność przyrody i człowieka. Najprościej rzecz ujmując: $\mathrm{z}$ racji posiadania umysłu człowiek może być traktowany jako coś znacznie większego niż tylko element w całościowej strukturze przyrody. Spinoza optował za stanowiskiem, wedle którego istota ludzka nie jest bytem wyróżnionym. Obstawanie przy tym poglądzie powinno zatem uwzględniać taki rodzaj dowodzenia, który zawiera również argumenty przemawiające za

\footnotetext{
14 „Czymże więc jestem? Rzeczą myślącą; ale co to jest? Jest to rzecz, która wątpi, pojmuje, twierdzi, przeczy, chce, nie chce, a także wyobraża sobie i czuje”. Kartezjusz, „Medytacja druga: O naturze umysłu ludzkiego. Że jest on bardziej znany niż ciało", 34 .

${ }_{15}$ Żelazna, „Modus (modi, modyfikacje)”, w: Substancja jak światło? Wybrane pojęcia i problemy filozofii Spinozy, 98-99.
} 
tym, że dziedzina myśli i umysłu nie pociąga za sobą uznania człowieka za byt wyjątkowy ${ }^{16}$.

\subsection{Swoistość myślenia ludzkiego}

Na gruncie spinozyzmu zdolność myślenia dotyczy zarówno człowieka, jak i wszystkich pozostałych bytów w przyrodzie ${ }^{17}$. Autor Etyki dochodzi do takiego wniosku, uwzględniając przy tym następujące twierdzenia. Przede wszystkim każda partykularna modyfikacja jest rzeczą, poprzez którą wyrażane są atrybuty jedynej substancji. Z tego powodu każda poszczególna rzecz musi być nacechowana naturą każdego $\mathrm{z}$ tych atrybutów. Jest to rezultatem tego, że substancja boska jest immanentnym, ostatecznym określeniem partykularnych rzeczy. To z kolei powoduje, że konieczne staje się, aby każdy poszczególny byt uczestniczył w substancjalnym atrybucie myślenia. Czy w związku z tym można pokusić się o stwierdzenie, że myślenie jest ograniczone do cech rozciągłych? Umysł w takiej sytuacji wprawdzie istnieje, nie jest jednak czymś odrębnym i niezależnym od bytu cielesnego. Spinoza takiej idei się przeciwstawiał. Analogicznie do swojego poprzednika twierdził, że idea myślącej materii nie współgra z ideą pojęciowej niezależności atrybutów myślenia i rozciągłości. Podobnie jak Kartezjusz uważał, że sfera myślenia jest niezależna względem materii. Niemożliwa staje się próba uzasadnienia jej cielesnymi czynnikami. W odróżnieniu jednak od francuskiego uczonego Spinoza nie zgadzał się ze stanowiskiem, wedle którego stwierdzenie dotyczące różnicy między sferą myślenia a sferą rozciągłości miało pociągać

${ }^{16}$ Gut, „Panpsychizm: Czy człowiek jest bytem ontycznie wyjątkowym ze względu na myślenie?", 82.

${ }^{17}$ Mówienie o zdolności myślenia w odniesieniu do wszystkich bytów w przyrodzie może być mylące, jeżeli rozumiemy myślenie po kartezjańsku, a mianowicie jako proces świadomy. Na gruncie spinozyzmu idee -modyfikacje z punktu widzenia atrybutu myślenia - przedstawiają coś, ale nie musi ich cechować świadomość. „Nieskończona możność myślenia” rzeczy dopuszcza rozróżnienie na świadome i nieświadome stany umysłu. Oczywiście w pełni rozwiniętym myśleniem (świadomym myśleniem) dysponują wyłącznie ludzie. Myślenie jednakże istnieje w każdym poszczególnym bycie. Jest tak ponieważ myślenie stanowi naturalną własność całej przyrody. Spinoza każdej rzeczy przypisuje zatem myślenie, choć poszczególnym bytom właściwe są różne stopnie życia umysłowego. W konsekwencji myślenie w różnych rzeczach przejawia się z odmienną intensywnością, odpowiednio do poziomu złożoności oraz siły istnienia danego bytu. 
za sobą tezę o traktowaniu istoty ludzkiej jako bytu wyjątkowego na tle całej przyrody. To, że myślenia nie da się sprowadzić do cielesności, wskazuje wyłącznie na to, że każda próba materialistycznego wyjaśnienia dziedziny umysłu musi zostać skazana na porażkę. Nie oznacza to jednak, że podmiot rozumiany jako istota, która myśli, ma naturę bytu duchowego i dlatego nie można jej interpretować w kategoriach odpowiednich dla natury. Byłoby to możliwe, gdyby przyrodę charakteryzowały jedynie właściwości adekwatne do atrybutu rozciągłości. Na gruncie spinozyzmu zaś natura jest kreacją, którą można analizować zarówno z perspektywy atrybutu rozciągłości, jak i z perspektywy atrybutu myślenia. Myślenie zatem powinno się uznać za powszechną cechę przyrody.

W drugiej księdze Etyki zawarty jest aksjomat: „Człowiek myśli”"18. Czyżby jednak Spinoza, podążając śladami Kartezjusza, przyznał istocie ludzkiej wyjątkową rolę ze względu na przynależną jej funkcję myślenia? Czy niderlandzki myśliciel przystał na to, jak chciał jego poprzednik, że umysł jako byt, który poznaje sam siebie „bardziej adekwatnie” niż swe własne ciało, jest cechą reprezentatywną i wyróżniającą ludzkość spośród całego porządku przyrody? Trudno jest odpowiedzieć na to pytanie z oczywistej przyczyny. Jasnej i wyraźnej, niepozostawiającej żadnych wątpliwości, definicji terminu „człowiek” nie znajdziemy na stronnicach Spinozjańskiej Etyki.

Kwestia ta budzi wiele problemów interpretacyjnych. Nasuwa się pytanie, czy myślenie jako powszechna cecha przyrody, myślenie jako właściwość przypadająca $w$ udziale każdej rzeczy ma takie samo znaczenie, co myślenie podmiotu ludzkiego. Spinoza twierdził, że tylko człowiek charakteryzuje się rozwiniętym umysłem, dla którego stwierdzona jest zdolność świadomego myślenia $w$ najwyższym stopniu. Uważał jednakże, że tezy proklamujące uniwersalność, wyjątkowość myślenia czy też jej trwałe osadzenie w rzeczywistości są przesadzone. Myślenie nie jest niczym niezwykłym, dostępnym wyłącznie mędrcom bądź prorokom. Jest ono przypisane każdemu jednostkowemu bytowi. W przypadku różnych rzeczy charakteryzuje się ono odmienną mocą. Intensywność ta jest zależna od złożoności oraz siły istnienia partykularnego bytu. Podsumowując: na gruncie spinozyzmu każdej rzeczy przysługuje myślenie, które w zależności od pewnych aspektów może mieć

\footnotetext{
${ }^{18}$ Spinoza, „Część druga: O naturze i pochodzeniu duszy”, 62.
} 
inny stopień nasilenia. Dla każdego bytu zatem charakterystyczna jest zdolność myślenia, może ono być nieświadome bądź świadome w mniejszym stopniu. „Albowiem to, co okazaliśmy do tej pory, jest bardzo ogólne i odnosi się do ludzi nie bardziej, niż do innych jednostek, jako że wszystkie one są uduchowione, choć w różnym stopniu” ${ }^{19}$. Jednakże „Dusza ludzka poznaje nie tylko pobudzenia ciała, lecz i idee tych pobudzeń”. I dalej: „Dusza ludzka posiada wiedzę (cognoscit) o samej sobie o tyle tylko, o ile poznaje (percipit) idee pobudzeń ciała"20.

Ludzki umysł posiada zatem zdolność do refleksji, uświadamiania sobie pewnych treści przedmiotowych, może tworzyć idee idei. Predyspozycja ta jest własnością jedynie niektórych idei. Biorąc pod uwagę spinozjańską zasadę paralelizmu, należy zaznaczyć, że zdolność ta musi być własnością jedynie niektórych ciał. Mowa tutaj oczywiście o człowieku. Co ważne, podmioty ludzkie zdają sobie sprawę z tego, że ich poznanie jest fragmentaryczne względem struktury całości. Możliwe, iż jest to wynikiem tego, że potencjał do refleksji pociąga za sobą umiejętność do ujmowania granic. Idea przedmiotu posiadającego granice ma sens tylko wówczas, gdy rozpatrujemy ją z perspektywy przedmiotu w żaden sposób nieograniczonego, a mianowicie substancji boskiej.

Koncepcja, że idea tego, co nieskończone, determinuje poznanie samego siebie pojawia się już w Kartezjańskich Medytacjach o pierwszej filozofii $i^{21}$. Dla Spinozy do prawidłowego używania umysłu konieczny jest pewien wzorzec, podobnie jak prawidłowe sterowanie działaniem zakłada pewien szczególny, etyczny model istoty ludzkiej. Wzorzec ten jest ideą wrodzoną regulującą

19 Tamże, 76.

20 Tamże, 92.

${ }^{21}$ „I naprawdę nie ma w tym nic dziwnego, że Bóg, stwarzając mnie, zaszczepił we mnie tę ideę, by była jak gdyby znakiem, którym artysta naznaczył swoje dzieło. Nie trzeba też wcale, by ten znak był czymś różnym od samego dzieła, lecz na podstawie tego tylko, że Bóg mnie stworzył, jest bardzo wiarygodne, że mnie stworzył w pewien sposób na obraz i podobieństwo swoje i że to podobieństwo, które zawiera ideę Boga, ujmuję przy pomocy tej samej zdolności, przez którą ujmuję siebie samego. To znaczy, że gdy skieruję uwagę na siebie samego, to nie tylko pojmuję, że jestem rzeczą niezupełną i zależną od kogoś innego, rzeczą, która dąży nieograniczenie do czegoś coraz większego, czyli lepszego, lecz pojmuję także równocześnie, że ten, od którego jestem zależny, posiada te wszystkie rzeczy większe nie w jakiś sposób nieokreślony i potencjalny tylko, lecz rzeczywiście ma je w sobie w stopniu nieograniczonym, przeto jest Bogiem”. Kartezjusz, „Medytacja trzecia: O Bogu, że istnieje”, 56. 
odpowiednie kierowanie umysłem. Do tego wzorca istotę ludzką przybliżyć może opanowywanie za pośrednictwem zdolności do refleksji coraz większego zakresu idei ${ }^{22}$.

\section{Konsekwencje moralne spinozyzmu. Umysł ludzki jako fundamentalny punkt oparcia na drodze prowadzącej do wolności i szczęścia}

Spinozjańska Etyka miała za zadanie pokazać, kim jest człowiek w przyrodzie. Poprawa pracy rozumu, jak postulował Kartezjusz, nie jest dla niderlandzkiego myśliciela celem samym w sobie. Kilka z fundamentalnych pytań pojawiających się w tym dziele jest następujących: kiedy możliwe jest i jak się przejawia działanie ludzkie? Czy człowiek pozostaje zależny i jedynie podlega działaniu? W jakim przypadku możemy mówić o aktywnym i niezdeterminowanym działaniu podmiotu ludzkiego (jeżeli w ogóle możemy)? Czy w czasie, gdy człowiek doświadcza działania natury może on sprawić, by uniknąć wszelkiego podporządkowania? Istota ludzka w przeciwieństwie do przyrody rozumianej jako substancja nie jest przyczyną samej siebie. Ulega, jak każdy inny byt, wszechstronnemu zdeterminowaniu. Czy może on zatem być wolny? Czy na gruncie spinozyzmu mamy do czynienia z rozumieniem wolności różnym od tego, które funkcjonowało w tradycji filozoficznej? Spinoza zdawał sobie sprawę z zamieszania, które mogą powodować zaproponowane przez niego pojęcia wolności oraz konieczności. Podejmował nieustanny wysiłek zmierzający do obalenia antonimicznego rozumienia tych idei. Relacja między podmiotem ludzkim a przyrodą wydaje się odbiegać od koncepcji zaproponowanej przez Kartezjusza. Natura nie czyni dla człowieka żadnego wyjątku. Istocie ludzkiej nie przysługuje zdolność spontanicznego działania. Czy bez założenia o potencjale do spontanicznego działania, wolnego, wyswobodzonego wobec wszelkich empirycznych, zewnętrznych okoliczności, możemy mówić o człowieku wolnym?

22 Anna Tomaszewska, „Etyka Spinozy a problem poznania transcendentalnego”, Studia z Historii Filozofii 4 (2013): 119. 
Można zauważyć, że spinozjańskiej filozofii czegoś brakuje. Tym czymś wydaje się wolny, myślący podmiot ludzki, który stanowił siłę napędową kartezjańskiego systemu. Co prawda Spinoza, za swoim poprzednikiem, przyjmuje aksjomat, że „człowiek myśli”, przyjmuje również kartezjańską zasadę idei jasnych i wyraźnych. Jednakże w żadnym ze stwierdzeń podmiotu ludzkiego nie odnajdziemy cudownej władzy, nie odnajdziemy żadnego "ja”, które miałyby nas uchronić przed całkowitym wątpieniem, tak jak postulował Kartezjusz. Nie ma tutaj miejsca na indywidualną perspektywę podmiotu ludzkiego. $\mathrm{Z}$ tego też względu nie można już mówić o istocie ludzkiej jako bycie wyróżnionym. Spinoza nie odnajduje w kartezjańskim cogito żadnej szczególnej zdolności poza zasadą idei jasnych i wyraźnych. Ona jednak nie przedstawia rzeczywistości z perspektywy podmiotu, lecz z perspektywy wieczności, a mianowicie z punktu widzenia Boga. Indywiduum ludzkie to wyłącznie modyfikacja Boga, determinowana przez te same prawa, jakie rządzą wszystkim. Tymczasem to właśnie w takim obiektywnym, pozbawionym wszelkiej partykularnej jaźni ujęciu świata, zdaniem Spinozy, możliwe jest odnalezienie fundamentu swych postulatów moralnych. Wzniesienie się ponad złudną i mętną perspektywę, charakterystyczną dla nastawienia naturalnego, zbliża nas do punktu widzenia przynależnego Bogu. Tylko w ten sposób możliwe jest osiągnięcie prawdziwej rozumowej wolności, która jest najwyższym z potencjalnych celów człowieka.

Droga do wolności polega na scaleniu się z rozumem. Koniecznym krokiem do osiągnięcia takiego stanu jest wyzwolenie się podmiotu ze wszelkich aspektów niepowiązanych z racjonalnym życiem. Mowa oczywiście o afektach, których źródłem są nieadekwatne idee. Teorię afektów (passions) odnajdziemy już u Kartezjusza w traktacie Namiętności duszy napisanym w 1646 roku. Może dziwić fakt, że francuski myśliciel poświęcił tyle uwagi rozważaniom dotyczącym uczuć, wydającym się mieć mniejsze znaczenie dla istoty jego koncepcji. Na Kartezjańską teorię popędów duszy warto zwrócić uwagę dlatego, że afekty, choć ich przyczyny mają wymiar cielesny, są mimo to stanami umysłu człowieka. Istota ludzka jest połączeniem zarówno pierwiastka niematerialnego, jak i materialnego, i związek ten skutkuje takimi wzruszeniami, które silnie wpływają na duszę. Przykładowo mogą zakłócać jej harmonię, jej stan równowagi, do której dusza z racji swej istoty dąży. Przez to, co zachodzi w ciele, umysł może być niejako wyrwany z natural- 
nych dla niego czynności ${ }^{23}$. Niemniej jednak nie należy afektów uważać za coś z istoty swej negatywnego i sprzeciwiającego się naturze ludzkiej. Trzeba je rozważać jako modyfikacje umysłu.

Według Spinozy Kartezjańska teoria afektów miała kilka mankamentów. Francuski myśliciel, sprowadzając przyczyny namiętności do czynników materialnych, nie uwzględnił ich umysłowego wymiaru. Dla Spinozy każdy afekt ma naturę rozciągło-umysłową. $Z$ jednej strony zatem istnieje jako pobudzenie, $\mathrm{z}$ drugiej zaś jako idea tego pobudzenia. $Z$ perspektywy umysłowego wymiaru afekty mają przede wszystkim charakter poznawczy. Wiążą się z przejściem od jednej idei w umyśle do następnej i analogicznie od jednej idei stanu ciała do następnej, powodując jednocześnie określone pragnienia, które z kolei motywują do działania ${ }^{24}$. Z tego powodu Spinozjańska teoria afektu różni się od tej, jaką zaproponował francuski myśliciel i według której przyczynami powstawania poruszeń są mechanizmy fizjologiczne. Co więcej, dla Kartezjusza wszystkie poruszenia duszy są doznaniami, nie zaś - jak chciał Spinoza - czynnościami. Przy takim rozumieniu afektów jako doznań spowodowanych przez przyczyny cielesne należałoby przyjąć, że człowiek wobec wszystkich namiętności zawsze pozostaje bierny. Dla niderlandzkiego myśliciela nie do przyjęcia było również Kartezjańskie stwierdzenie, że dusza za pośrednictwem woli może, według własnych wskazań, kontrolować wszelkie uczucia. Mimo tych krytycznych uwag Spinoza z pewnością doceniał fakt, że Kartezjusz zajął się naturą afektów i dokonał ich klasyfikacji.

Wracając do spinozjańskiej teorii afektów: jeżeli mamy kontrolę nad oddziaływaniem poruszeń biernych, to nasze działanie oraz odczuwanie stają się odpowiednie dla tego, czego domaga się od nas rozum. Naturalnie, im bardziej panujemy nad afektami, tym większą mocą działania dysponujemy i w rezultacie tym bardziej jesteśmy wolni. Kontrola nad namiętnościami nie jest niewątpliwie łatwym zadaniem. Dla Spinozy człowiek może stać się przyczyną adekwatną pewnego skutku, jeżeli tak zorganizuje swoje myślenie, by funkcjonowały w nim wyłącznie idee adekwatne. Ta konkretna modyfikacja jest w stanie zrozumieć istotę swojego działania pod warunkiem, że posiada

${ }^{23}$ Tomasz Śliwiński, „Teoria uczuć duszy”, w: Mistrz i kontynuator: René Descartes i Louis De La Forge (Łódź: Wydawnictwo Uniwersytetu Łódzkiego 2013), 469.

${ }^{24}$ Gut, „Działanie”, 252. 
jasne i wyraźne ujęcie swojego pobudzenia. Jeżeli źródło tego pobudzenia znajduje się w innej modyfikacji natury, istota ludzka pozostaje bierna. Jeżeli zaś jest ona przyczyną tego pobudzenia, modyfikacja wtedy działa i jest tym samym adekwatną przyczyną swojego pobudzenia. Taki stan rzeczy jest możliwy tylko wtedy, gdy umysł jest w posiadaniu adekwatnych idei. „Wszystkie idee, o ile odnoszą się do Boga, są prawdziwe [...], tj. [...] adekwatne”. I dalej: „Idea Boga, będąca w nas, jest adekwatna i doskonała [...], dlatego też, o ile rozmyślamy o Bogu, o tyle jesteśmy czynni”25.

Kiedy umysł zaś rozważa swoją istotę jako modyfikację Boga, to ujmuje siebie tak samo, jak widzi ją Bóg. Jest to poznanie prawdziwe - adekwatne. Takie adekwatne samopoznanie jest możliwe wyłącznie w przypadku bytu myślącego, o ile jest on ideą ludzkiego ciała. Żeby można było posiadać idee adekwatne, należy przede wszystkich ujmować idee jako modyfikacje natury. Innymi słowy: konieczny jest ogląd rzeczywistości pozwalający nam postrzegać przyrodę jako różnorodny łańcuch rzeczy, w którym wszelkie zmiany wynikają z innych modyfikacji. Niezbędny jest taki proces rozumowania i rozumienia, w którym ujmujemy, że ciała oddziałują na siebie wzajemnie. Natura jest przyczyną adekwatną każdej zmiany. Każda modyfikacja istnieje zatem jako sposób istnienia jednej i jedynej substancji. Umysł ludzki, który rozumie siebie jako modyfikację natury jednej jedynej substancji, ujmuje status własnego istnienia jako taki akt natury, który jest konieczny i niezmienny. Kiedy zatem kierujemy naszą uwagę ku naturze, wtedy działamy, ponieważ działa w nas jedna i jedyna substancja. Jest to najszczęśliwszy z możliwych stan umysłu ludzkiego ${ }^{26}$. Sposobność do osiągnięcia tego rodzaju mocy jest udziałem jedynie człowieka. Zważywszy na ten fakt, można pokusić się o stwierdzenie, że możliwość ta czyni istotę ludzką bytem wyjątkowym.

\footnotetext{
${ }^{25}$ Spinoza, „Część piąta: O mocy rozumu, czyli o wolności ludzkiej”, 322.

${ }^{26}$ Jolanta Żelazna, „Wolność od przypadkowości”, w: Spinozjańska teoria afektów, (Toruń: Wydawnictwo Naukowe Uniwersytetu Mikołaja Kopernika 2010), 342.
} 


\section{Zakończenie}

Czy kartezjanizm możemy traktować jako źródło spinozyzmu? Niezachwiana wiara odnośnie do możliwości autonomicznego rozumu człowieka, bezgraniczne zaufanie do jednostki ludzkiej jako istoty myślącej, rozpowszechnianie wysiłku rozumowego, za pośrednictwem którego postuluje się ogarnięcie całej otaczającej nas rzeczywistości - to z pewnością niepowątpiewalne dobra odziedziczone przez Spinozjańską myśl po tradycji kartezjańskiej. Spuścizną po francuskim myślicielu był także sposób ujmowania zasięgu działań intelektu w formie matematycznej. Zamierzenie przedstawienia całości wiedzy w postaci systemu aksjomatów, geometryzacja metody, poszukiwanie prawd prawdziwych samych przez się przeciwstawiających się świadectwom zmysłów to również owoce inspiracji spinozyzmu Kartezjańskimi pomysłami. Ale jakże bardzo różniły się obie doktryny w punkcie wyjścia, obranym kryterium prawdziwości, metodą uzasadniania wiedzy koniecznej, wreszcie stosunkiem do roli człowieka we wszechświecie. Kartezjański model myślenia, umysłu uczynił z człowieka na tle całej przyrody byt ontycznie wyjątkowy. Spinoza zaś opowiadał się za stanowiskiem, wedle którego istota ludzka ze względu na swoje myślenie nie jest rzeczą wyróżnioną. Jednak człowiek w spinozjańskim systemie odgrywa rolę wyjątkową. Potwierdzeniem tego jest ogromny wysiłek, jaki ten niderlandzki myśliciel włożył w budowę całej swej metodologii ${ }^{27}$. Spinoza, tworząc ją, miał na uwadze przede wszystkim wynikające z niej konsekwencje moralne. W przeciwieństwie do Kartezjusza, którego celami były: metamorfoza nauki, usiłowanie podporządkowania filozofii oraz specyficznej dla niej metody zadaniu udoskonalania przyrodoznawstwa, prawo człowieka do ingerencji w otaczające go rzeczy, Spinoza koncentrował się na istocie ludzkiej. Niderlandzki myśliciel był przede wszystkim propagatorem życia moralnego. Za pomocą oczyszczenia ludzkich sposobów rozumowania pragnął uwolnić jednostki ludzkie od destrukcyjnych afektów, służalczości, poczucia winy, przesądów i nieto-

\footnotetext{
${ }^{27}$ Leszek Kołakowski, „Tradycja racjonalizmu i jej przezwyciężenie”, w: Jednostka i nieskończoność. Wolność i antynomie wolności w filozofii Spinozy (Warszawa: Wydawnictwo Naukowe PWN, 2011), 73-75.
} 
lerancji. Głównym postulatem spinozjańskiej etyki zatem jest usposobienie do coraz bardziej intuicyjnego i filozoficznego rozumienia drogi samodoskonalenia się jednostki ludzkiej. Niderlandzki myśliciel szybko orientuje się, iż fundamentalnego punktu oparcia, jedności łączącej moje ,ja” z otaczającą nas przyrodą, należy poszukiwać w umyśle ludzkim. Z tego właśnie względu człowieka możemy traktować jako byt wyróżniony.

\section{Bibliografia}

Ganowicz-Bączyk Anita. 2011. „Wpływ nowożytnego antropocentryzmu na relację człowieka do przyrody. Część pierwsza”. Studia Ecologiae et Bioethicae 9: 9-27.

Gut Przemysław. 2011. Spinoza o naturze ludzkiej. Lublin: Wydawnictwo KUL.

Husserl Edmund. 2009. „Medytacje Kartezjusza jako wzór filozoficznej autorefleksji”. W: Medytacje kartezjańskie, przeł. Andrzej Wajs. 1-10. Warszawa: Wydawnictwo IFiS PAN.

Kartezjusz. 2010. Medytacje o pierwszej filozofi, przeł. Maria i Kazimierz Ajdukiewiczowie. Warszawa: Wydawnictwo Naukowe PWN.

Kołakowski Leszek. 2012. „Tradycja racjonalizmu i jej przezwyciężenie”. W: Jednostka i nieskończoność. Wolność i antynomie wolności w filozofii Spinozy, 69-89. Warszawa: Wydawnictwo Naukowe PWN.

Michalski Krzysztof. 1985. „Husserl i Kartezjusz: Kiedy świat wydaje nam się niezrozumiały". Studia Filozoficzne 4: 3-16.

Pasieka Paweł. 2012. „Kartezjańska koncepcja zwierzęcia-maszyny”. Filo-Sofija 17: 51-64.

Spinoza Baruch. 2010. Etyka w porzadku geometrycznym dowiedziona, przeł. Ignacy Myślicki. Warszawa: Wydawnictwo Naukowe PWN.

Śliwiński Tomasz. 2013. „Teoria uczuć duszy”. W: Mistrz i kontynuator: René Descartes $i$ Louis De La Forge, 466-477. Łódź: Wydawnictwo Uniwersytetu Łódzkiego.

Tomaszewka Anna. 2013. „Etyka Spinozy a problem poznania transcendentalnego”. Studia $z$ Historii Filozofii 4: 113-125.

Żelazna Jolanta. 1995. „Wstęp”. W: Skończone poznanie ludzkie w filozofii Spinozy, 5-16. Toruń: Wydawnictwo Uniwersytetu Mikołaja Kopernika.

Żelazna Jolanta. 2010. „Modus (modi, modyfikacje)”. W: Substancja jak światło? Wybrane pojęcia i problemy filozofi Spinozy, 85-105. Toruń: Wydawnictwo Naukowe Uniwersytetu Mikołaja Kopernika.

Żelazna Jolanta. 2010. „Wolność od przypadkowości”. W: Spinozjańska teoria afektów, 340-346. Toruń: Wydawnictwo Naukowe Uniwersytetu Mikołaja Kopernika. 


\section{Abstract \\ Baruch Spinoza’s Connections with Descartes's Philosophy. The Issue of Human Thinking}

The article makes an attempt to compare two perspectives: a perspective which can be found in Descartes's Meditations and another which can be observed in Spinoza's Ethics. There is no doubt as to the influence Descartes had on Spinoza's philosophy, yet they had different goals. The concept of human thinking proposed by the author of the Ethics was entirely different from the idea of mind offered by Descartes. For Spinoza, thinking is not attributed exclusively to a human being. It is a universal quality which relates to the whole of nature. It has nothing to do with distinct state of being human. But the conception developed by Spinoza is one of the most important propositions pointing to the outstanding role of human nature.

Key words: Spinoza; Decsartes; mind; freedom; substance.

\section{Streszczenie}

\section{Baruch Spinoza i jego związki z filozofią Kartezjusza. Problem myślenia ludzkiego}

W artykule podejmuję próbę porównania dwóch filozoficznych perspektyw, jakie odnajdujemy na stronnicach Kartezjańskich Medytacji i Spinozjańskiej Etyki. Mimo niezaprzeczalnego oddziaływania myśli Kartezjusza na system Spinozy filozofowie ci mieli odmienne cele. Koncepcja natury ludzkiego myślenia zaproponowana przez autora Etyki różni się znacząco od propozycji przedstawionej przez francuskiego uczonego. Dla Spinozy myślenie nie jest specyficznie ludzką własnością. Jest cechą uniwersalną i odnosi się do całej przyrody. Kategoria myślenia ludzkiego nie czyni człowieka bytem wyróżnionym. Mimo to Spinozjańską koncepcję należy traktować jako jedną z najważniejszych propozycji przedstawiających wyjątkową rolę natury ludzkiej.

Słowa kluczowe: Spinoza; Kartezjusz; umysł; wolność; substancja. 